\title{
APLIKASI PENGENALAN HEWAN BERMETAMORFOSIS DENGAN MENGGUNAKAN AUGMENTED REALITY BERBASIS ANDROID
}

\author{
Maya Selvia Lauryn ${ }^{1)}$, Muhamad Ibrohim ${ }^{2)}$ Puput Purnamasari ${ }^{3)}$ \\ 1,2,3 Fakultas Teknologi Informasi, Universitas Serang Raya \\ email: Mysellyn@gmail.com, b41m.cyber@gmail.com, purnamasaripuput36@gmail.com
}

Article history Received Sep 4, 2020 2020

Accepted Nov 20, 2020

Available online Nov 30,2020

Keywords Augmented Reality, metamorfosis dan Android
Revised Okt 10,

\begin{abstract}
At SD Negeri Talaga, animal learning metamorphosis still uses conventional media, so students are not interested and quickly get bored in learning lessons about metamorphosis. And also because of the une pull of learning media today many students who find it difficult in the introduction of animals around their environment. So it is necessary to have a medium of introduction of metamorphosis animals. This research uses Luther Sutopo version of software development method consisting of six stages, namely Concept, Design, Material Collection, Assembly, Testing, and Distribution. And made using software CorelDraw X7, Blender 3D, Unity 2018, Android Vuforia SDK. The end result of an animal recognition app metamorphoses using Android-based Augmented Reality distributed to the android play store, so it can be uploaded and used for students elsewhere who want to learn and understand the introduction of metamorphosis animals.
\end{abstract}

Keywords: Augmented Reality, metamorfosis dan Android

Riwayat

Diterima 4 Sept

2020

Revisi 10 Oct,

2020

Disetujui 20 Nov

2020

Terbit 30 Nov 2020

Kata Kunci

Augmented Reality

metamorfosis dan

Android

\section{Abstrak}

Pada SD Negeri Talaga pembelajaran hewan metamorfosis masih menggunakan media konvensional, sehingga siswa tidak tertarik dan cepat merasa bosan dalam mempelajari pelajaran tentang metamorfosis. Dan juga karena tidak menariknya media pembelajaran saat ini banyak siswa yang merasa kesulitan dalam pengenalan hewan disekitar lingkungannya. Sehingga diperlukan adanya media pengenalan hewan metamorfosis. Penelitian ini menggunakan metode pengembangan perangkat lunak versi Luther Sutopo yang terdiri dari enam tahapan yaitu Concept, Design, Material Collection, Assembly, Testing, dan Distribution. Dan dibuat menggunakan software CorelDraw X7, Blender 3D, Unity 2018, Android Vuforia SDK. Hasil akhir sebuah aplikasi pengenalan hewan bermetamorfosis dengan menggunakan Augmented Reality berbasis Android yang di distribusikan ke play store android, sehingga dapat diunggah dan digunakan bagi siswa di tempat lain yang ingin belajar serta memahami pengenalan hewan bermetamorfosis.
\end{abstract}

Keywords: Augmented Reality, metamorfosis dan Android

\section{PENDAhULUAN}

Pada masa sekarang media penyampaian informasi dapat menggunakan gambar 3D agar informasi yang diberikan lebih jelas dan lebih efektif. Salah satu teknologi yang menggunakan gambar 3D yaitu Augmented Reality (AR). Augmented Reality (AR) merupakan sebuah media baru penyampaian informasi yang sedang berkembang saat ini. Dengan adanya AR seorang pengguna dapat merasakan penyampaian informasi yang lebih menarik dan lebih nyata. Untuk dapat menyajikan informasi yang benar ke dalam dunia nyata, 
AR membutuhkan sebuah marker. Fungsi adanya marker di dalam sebuah teknologi AR adalah untuk memunculkan sebuah objek 3D yang kemudian ditampilkan ke layar monitor handphone android. Teknologi AR ini dapat digunakan sebagai media pembelajaran yang menarik bagi anak-anak, misalnya tentang metamorfosis pada serangga.

Metamorfosis adalah perubahan/perkembangan biologi yang terjadi pada diri makhluk hidup hewan yang berawal dari telur hingga menjadi dewasa secara sempurna dengan mengalami perubahan pada bentuk anatomi, morfologi maupun fisiologis. Dalam bermetamorfosis tersebut dibagi menjadi dua jenis yaitu metamorfosis sempurna dan metamorfosis tidak sempurna.

Metamorfosis atau daur hidup termasuk kedalam pelajaran IPA. Seperti pada SD Negeri Talaga pelajaran tentang hewan metamorfosis diajarkan pada kelas 4 . Pembelajaran hewan metamorfosis masih menggunakan media konvensional dan nilai rata-rata siswa masih dibawah 70 . Maka hal tersebut membuat siswa tidak tertarik dan cepat merasa bosan dalam mempelajari hewan metamorfosis. karena siswa tidak tertarik mereka tidak begitu menangkap dan memahami materi yang diajarkan oleh gurunya. maka hal tersebut membuat siswa sulit mengenali hewan metamorfosis disekitar lingkungannya.

Sehingga diperlukan adanya media pengenalan hewan metamorfosis yang dapat menarik perhatian serta informatif bagi anak-anak dengan memanfaatkan teknologi Augmented Reality. Media pembelajaran tersebut mencakup pelajaran tentang hewan metamorfosis.

Diharapkan dengan adanya aplikasi ini dapat membantu anak-anak untuk lebih mengenali hewan-hewan metamorfosis terutama hewan yang berada disekitar lingkungannya.

\section{KAJIAN LITERATUR}

\subsection{Daur Hidup (Metamorfosis)}

Proses urutan kejadian yang dialami makhluk hidup selama hidupnya disebut daur hidup. Karena daur hidup membentuk pola melingkar, maka daur hidup dapat disebut lingkaran hidup atau siklus hidup. Perubahan struktur/rupa/bentuk yang mencolok dalam perkembangan makhluk hidup disebut metamorfosis. Metamorfosis ada yang lengkap (sempurna) ada juga yang tidak lengkap (tidak sempurna). (Purwo Sutanto, Sarjan, Handayani, 2004: 32). Metamorfosis sempurna dialami hewan yang saat lahir berbeda sekali bentuknya dengan hewan dewasa. Metamorfosis sempurna terdiri atas empat tahap, yaitu telur-larva-pupa-dewasa. (Haryanto, 2013: 51)

Metamorfosis tidak sempurna dialami serangga yang dari lahir tidak terlalu berbeda bentuknya dengan hewan dewasa. Metamorfosis tidak sempurna hanya tiga tahap, yaitu telur-nimfa-dewasa. Contoh metamorfosis lengkap adalah kupu-kupu dan metamorfosis tidak lengkap adalah kecoa. (Haryanto, 2013: 53)

\subsection{Daur Hidup Kupu-Kupu}

Kupu-kupu adalah serangga anggota Lepidoptera, dengan sayap berbagai corak dan warna. Kupu-kupu terdapat dimanamana, kecuali di daerah beriklim dingin. Pada umumnya kupu-kupu makan dengan cara mengisap cairan madu dari tanaman atau hektar. Dengan begitu kupu-kupu juga mengemban tugas untuk melakukan penyerbukan tanaman. Kupu-kupu mempunyai sepasang sayap depan dan sayap belakang. Sayap tersebut ditutupi oleh sisik yang mengandung pigmen. Pigmen itulah yang memberi warna dan corak pada sayap kupu-kupu. dibagian kepala terdapat antena yang digunakan untuk memonitor makanan dan lawan jenis. kupu-kupu bisa hidup selama 20-40 hari.

Daur hidup Kupu-Kupu. Dimulai dari telur. Telur kupu-kupu biasanya berada di permukaan daun. Telur menetas menjadi ulat. Ulat mempertahankan hidupnya dengan makan dedaunan selama berharihari. Akan tetapi, lama-kelamaan ulat makan makin sedikit. Demikian pula gerakan ulat, makin lama makin lambat. Akhirnya, ulat berhenti makan dan tampak tidak bergerak. Walaupun tidak makan dan tampak tidak bergerak, ulat itu tidak mati. Ulat segera membuat sarang dengan air liurnya. Air liurnya mengeras membentuk bahan semacam benang sutra. Benang- 
benang itu melekat pada daun atau batang. Akhirnya, benarg-benang itu menutup seluruh tubuh ulat. Keadaan ulat yang terbungkus dalam sarang benang itu disebut kepompong. Selama masa kepompong, ulat menjadi kupu-kupu. Masa kepompong berlangsung selama berharihari. Jika telah berubah secara sempurna, kupu-kupu keluar dari kepompong. Kupukupu hidup dengan menakan nektar yang ada didasar bunga. Kupu-kupu dewasa berkembang biak dengan bertelur. Dari telur ini, daur hidup kupu-kupu yang baru dimulai lagi. (Haryanto, 2013: 51)

\subsection{Daur Hidup Lebah}

Lebah adalah salah satu jenis serangga pemakan nektar atau serbuk sari yang suka hidup berkelompok. Lebah merupakan salah satu jenis serangga yang mengalami metamorfosis sempurna, yaitu telur-larvapupa-imago (lebah dewasa). Sarang lebah dibangun menggunakan perekat getah pohon dan malam yang diproduksi oleh lebah betina. Sarang ini biasanya berada di atas bukit, di pohon, dan atap rumah.

Telur lebah yang menetas akan menjadi larva. Pada tahap ini, lebah pekerja akan memberi makan larva, berupa serbuk sari, nektar, serta madu. Lebah pekerja akan mengumpulkan sebagian nektar untuk disimpan sebagai madu. Setelah beberapa hari, larva berubah menjadi pupa, lalu menjadi lebah dewasa. (Rani Yulianty, 2013:42)

\subsubsection{Daur Hidup Belalang}

Belalang termasuk serangga ordo Orthopedo. Memiliki dua pasang sayap dan mulut, tipe pengunyah. Makananya rumput dan dedaunan. Daur hidup atau metamorfosis belalang mengalami metamorfosis tidak sempurna. (Tamara Nurmutiah, 2009:55).

Daur hidup belalang dimulai dari tahap telur. Telur kemudian menetas menjadi belalang muda yang bentuknya menyerupai belalang dewasa. Akan tetapi, belalang muda belum memiliki sayap. Alat perkembangbiakannya juga belum sempurna. Belalang muda kemudian akan berganti kulit beberapa kali dan akhirnya tumbuh menjadi belalang dewasa. (Haryanto, 2013: 54)

\subsubsection{Daur Hidup Capung}

Capung terdapat di hampir semua tempat. Terutama yang berdekatan dengan air tawar seperti kolam, danau, dan sungai. Serangga ini termasuk ordo Anisoptern yang berekor panjang. Hewan ini memiliki dua pasang sayap tipis tembus pandang. Capung termasuk serangga penggigit dan pengunyah. Kelompok capung bersifat aerial, artinya sebagian besar hidupnya terbang. Meskipun demikian, kehidupannya di air sangat penting karena air merupakan tempat ia menggembangkan turunan. Capung terbang berpasangan antara yang jantan dan betina. Kecepatan terbangnya bisa mencapai $80-90 \mathrm{~km} / \mathrm{jam}$.

Perkawinan capung terjadi diudara dan setelah itu bertelur yang diletakkan didalam jaringan tumbuhan, di atas tanah atau di air. Setelah menetas akan membentuk nimfa atau larva yang bersifat akuatik. Pada saat itu, organ tubuhnya sudah berbentuk. Semua nimfa capung bersifat karnivora atau memangsa kawannya sendiri. Lalu setelah itu, nimfa capung akan berubah menjadi capung dewasa. Setelah dewasa, capung tersebut bertelur. daur hidup capung yang baru dimulai lagi. (Tamara Nurmutiah, 2009:55).

\subsection{Multimedia}

(Munir, 2013: 2) Pengertian multimedia dapat berbeda dari sudut pandang orang yang berbeda, Secara umum, multimedia berhubungan dengan penggunaan lebih dari satu macam media untuk menyajikan informasi. Misalnya, video musik adalah bentuk multimedia Karena informasi menggunakan audio/suara dan video, Berbeda dengan rekaman musik yang hanya menggunakan audio/suara sehingga disebut monomedia.

\subsection{Augmented Reality}

Menurut Ronald Azuma pada tahun 1997, augmented reality adalah menggabungkan dunia nyata dan virtual, bersifat interaktif secara real time, dan bentuknya merupakan animasi 3D. Yang dimaksud interaktif disini adalah, adanya interaksi dari user ke AR tersebut. Sehingga ada pengaruh di Augmented Reality tersebut, seperti misalnya, user menggunakan handphone 
yang terdapat tombol-tombol untuk menjalankan atau member efek pada Augmented Reality. Augmented Reality seperti biasanya ada digunakan smartphone untuk membuat Game Augmented Reality yang bersifat Interaktif. (Anggi Adriyadi, 2011: 1)

\subsection{Android}

Android adalah nama sebuah sistem operasi berbasis Linux yang ditujukan untuk perangkat bergerak dengan layar sentuh seperti smartphone dan komputer tablet. Awalnya android dibuat oleh perusahaan Android Inc sampai saat ini diakuisisi oleh Google pada tahun 2005. Berkat Google, kini Android semakin populer, terlebih lisensi yang digunakan adalah lisensi Open Source. Ikon Android juga cukup terkenal yaitu sebuah robot berwarna hijau. (Seno dan bowo,2013:2)

\subsection{Corel Draw}

CorelDraw adalah editor grafik vektor yang dikembangkan oleh corel, sebuah perusahaan perangkat lunak yang bermarkas di Ottawa, Kanada. Software ini berbasiskan pada sistem vektor, dan biasanya di pakai dalam suatu pembuatan objek (making image). Orientasi CorelDRAW merupakan salah satu aplikasi pengolah gambar berbasis vektor yang banyak dipakai oleh pengguna $\mathrm{PC}$, untuk dekstop publishing, percetakan dan bidang lain yang memerlukan pemrosesan visual. (Ibrahim Hanif, 2014: 1-2)

\subsection{Blender}

Blender adalah software modelling, rendering dan animasi 3 dimensi yang kini menjadi primadona animator indonesia dan seluruh dunia. Ukurannya yang (50 MB), kecepatan, kemudahan dan kelengkapannya bisa mengalahkan seniornya yaitu 3D Studio Max dan Maya. Selain modelling dan animasi 3D Blender juga bisa untuk video editing, video effects, image retouching, game development. (Hendi Hendratman, 2015:1).

\subsection{Unity}

Unity 3D atau yang lebih sering disebut Unity saja, adalah sebuah software pemrograman yang digunakan untuk membuat berbagai macam aplikasi. Mayoritas pengguna Unity adalah untuk pembuatan aplikasi Game. Tetapi dengan menggunakan Unity, anda dapat membuat berbagai macam aplikasi seperti presentasi, website, bahkan dapat digunakan untuk membuat Augmented Reality. Untuk membuat sebuat Augmented reality terlebih dahulu anda harus mengunduh software unity versi $5.0 \mathrm{ke}$ atas karena plugin vuforia hanyadapat digunakan pada unity versi 5 ke atas. Anda dapat mengunduh Unity lewat website resminya di unity3d.com. (Andre Kurniawan Pamoedji, Maryuni danRidwan Sanjaya, 2017: 15)

\subsection{Vuforia}

\subsection{1.}

Vuforia merupakan sebuah plugin dari software yang bernama Unity 3D. Untuk dapat membuat aplikasi Augmentd Reality ini juga memerlukan beberapa komponen dasar seperti model 3 dimensi sebagai objek yang akan muncul ketika pattern siscan dan dapat dibuat melalu 3ds max, Blender, Maya, atau program modeling 3D lainnya. Selain itu, membutuhkan sebuah gambar 2 Dimensi yang digunakan sebagai pattern yang dapat dibuat melalui software seperti Paint, Photoshop, Adobe Illustrator, dan berbagai software mengammbar 2D lainnya. Bahkan dapat mencari model 3D dan gambar 2D dari Google karena banyak orang yang membagikan hasil karya 3D dan 2D mereka secara gratis di internet. (Andre Kurniawan Pamoedji, Maryuni danRidwan Sanjaya, 2017: 15)

\section{METODE PENELITIAN}

Dalam penelitian ini mengambil lokasi di SD Negeri Talaga Mancak Serang. Setelah melakukan penelitian di SD Negeri Talaga, langkah selanjutnya adalah mengumpulkan data. Pengumpulan data yang dibutuhkan dalam penyusunan skripsi ini adalah sebagai berikut :

1. Metode Observasi

Observasi yaitu suatu cara pengumpulan data dengan pengamatan langsung dan pencatatan secara sistematis terhadap obyek yang akan diteliti. Observasi dilakukan oleh dengan cara mengamati kegiatan dan metode belajar 
mengajar di SD Negeri Talaga pada kelas 4.

2. Metode Wawancara

Metode wawancara dilakukan dengan guru yang melaksanakan pembelajaran di SD Negeri Talaga. Wawancara dalam penelitian ini untuk mengetahui tanggapan guru terhadap pelaksanaan pembelajaran yang telah dilaksanakan.

3. Kuesioner/Tes

Sebelum dilakukannya tindakan dengan menggunakan aplikasi media pembelajaran, terlebih dahulu dilakuka Pretest untuk mengetahui kemampuan awal siswa. Setelah dilakukan tindakan Pretest kemudian dilakukan Postest untuk mengetahui peningkatan kemampuan siswa.

4. Studi Literatur

Dalam melakukan penelitian ini menggunakan studi literatur sebagai bahan dasar dalam pembahasan masalah. Studi literatur yang dimaksud dapat berupa buku, e-book, jurnal atau sumber data yang membahas permasalahan yang sama tentang tema media pembelajaran untuk anak sekolah dasar.

\subsection{Perancangan Konsep (Concept)}

Penelitian ini adalah media pembelajaran pengenalan hewan bermetamorfosis dengan menggunakan augmented reality berbasis android (Studi Kasus: SD Negeri Talaga Mancak Serang), dengan tujuan untuk memberikan kemudahan dalam pengenalan hewan metamorfosis, dengan audiens siswa sekolah dasar tingkat $4 \mathrm{di}$ Sekolah Dasar Negeri talaga. Dalam aplikasi media pembelajaran ini juga menggunakan beberapa komponen multimedia seperti teks, gambar, animasi, dan audio. Gambar dalam aplikasi ini menggunakan format jpeg dan png. Sedangkan dengan animasinya aplikasi ini menggunakan format " $\mathrm{fbx}$ " format $\mathrm{fbx}$ adalah suaru objek yang memiliki texture, animasi dan 3D objek. Dan dalam aplikasi ini audio menggunakan format mp3. Ada tiga aspek penting di dalam pembelajaran kepada anak, yaitu kemudahan, menyenangkan, dan visual. Kemudahan tersebut baik fasilitas, media belajarnya maupun metode yang diterapkan. Oleh sebab itu, diperlukan metode belajar yang mengacu kepada tiga hal yaitu mudah, menyenangkan, dan mengandung visual. Dikarenakan perkembangan teknologi yang begitu pesat, hingga akhirnya anakanak banyak menghabiskan waktu untuk berinteraksi dengan Smartphone menyebabkan kurangnya daya tarik anakanak untuk mempelajari hewan disekitar lingkungannya, maka dengan memanfaatkan Teknologi Augmented Reality, Proses belajar anak lebih menarik dan menyenangkan disebabkan proses pembelajaran yang mengandung unsur mudah, menyenangkan dan visual.

\subsubsection{Identifikasi Sasaran Pengguna}

Dalam perancangan aplikasi media pembelajaran hewan bermetamorfosis ini ditargetkan untuk siswa kelas 4 sekolah dasar. Disamakan dengan kurikulum yang digunakan oleh sekolah tersebut. Siswa pun di perkenalkan teknologi augmented reality dengan objek 3D supaya siswa mampu mengenali dan memahami hewan metamorfosis yang ada di sekitar lingkungannya dengan mudah.

\subsubsection{Strategi Positioning}

Strategi yang diterapkan dalam media pembelajaran hewan bermetamorfosis adalah strategi positioning, karena strategi ini dapat membuat siswa lebih tertarik dalam mengenali hewan bermetamorfosis.

\subsubsection{Daya Tarik Positif}

Daya tarik yang digunakan dalam penyampaian pesan untuk aplikasi ini adalah daya tarik positif. Penyampaian pesan yang ada di dalam aplikasi ini mampu menampilkan pesan-pesan yang singkat, jelas dan padat, sehingga siswa dapat dengan mudah mencerna dan memahami pesan-pesan yang akan disampaikan. Maka daya tarik positif pun berfokus kepada kebutuhan siswa untuk mengenali hewan bermetamorfosis. Manfaat yang didapat oleh siswa kelas 4 sekolah dasar adalah kemampuan siswa dalam mengenali dan memahami hewan metamorfosis yang berada di sekitar lingkungan dan juga adanya aplikasi ini dapat meningkatkan kemauan dan kemampuan siswa dalam belajar terutama tentang hewan metamorfosis. Berikut perancangan konsepyang digunakan pada 
pembuatan aplikasi ini adalah sebagai berikut :

Tabel 3.1 Tabel Konsep Aplikasi

\begin{tabular}{|c|c|c|}
\hline No & Konsep & Keterangan \\
\hline 1 & Judul & $\begin{array}{l}\text { Aplikasi Pengenalan } \\
\text { Hewan } \\
\text { Bermetamorfosis } \\
\text { dengan } \\
\text { Menggunakan } \\
\text { Augmented Reality } \\
\text { Berbasis Android } \\
\text { (Studi kasus : SD } \\
\text { Negeri Talaga) }\end{array}$ \\
\hline 2 & Tujuan & $\begin{array}{l}\text { Membuat edukasi } \\
\text { pembelajaran dengan } \\
\text { konsep 3D yang } \\
\text { menggunakan } \\
\text { teknologi } \\
\text { Augmented Reality } \\
\text { (AR) untuk } \\
\text { mempermudah siswa } \\
\text { dalam mengenali } \\
\text { hewan metamorfosis }\end{array}$ \\
\hline 3 & Audiens & $\begin{array}{l}\text { Anak Sekolah Dasar } \\
\text { kelas } 4 \text { di SD Negeri } \\
\text { Talaga }\end{array}$ \\
\hline 4 & Durasi & Tak Terhingga \\
\hline 5 & Image & $\begin{array}{lll}\begin{array}{l}\text { Format } \\
\text {.jpeg }\end{array} & & \text { dan } \\
\end{array}$ \\
\hline 6 & 3 Dimensi & $\begin{array}{l}\text { Gambar } 3 \text { Dimensi } \\
\text { dengan format .fbx }\end{array}$ \\
\hline 7 & Interaktivitas & $\begin{array}{l}\text { Tombol mulai untuk } \\
\text { memindai atau } \\
\text { mendeteksi objek } 3 \\
\text { dimensi pada marker } \\
\text { yang tersedia, tombol } \\
\text { latihan untuk } \\
\text { menjawab soal-soal } \\
\text { yang ada, tombol } \\
\text { informasi untuk } \\
\text { belajar } \\
\text { menetahui informasi } \\
\text { tentang hewan } \\
\text { metamorfosis, } \\
\text { tombol petunjuk } \\
\text { untuk menunjukkan } \\
\text { cara penggunaan } \\
\text { aplikasi ini, tombol } \\
\text { tentang untuk masuk } \\
\text { kehalaman menu } \\
\text { tetang, tombol keluar } \\
\text { untuk keluar dari } \\
\text { aplikasi. }\end{array}$ \\
\hline
\end{tabular}

\subsection{Perancangan Desain (Design)}

Tahapan ini merupakan tahapan untuk merancang isi, struktur navigasi program dan tampilan aplikasi. Rancangan struktur navigasi program untuk menggambarkan hubungan aplikasi. Rancangan tampilan aplikasi keterkaitan setiap halaman dan juga menjelaskan arahan komunikasinya. Rancangan tampilan ini dibuat dengan rancangan yang menarik dan dapat di pahami oleh pengguna.

\subsubsection{Rancangan Struktur Navigasi}

Struktur navigasi adalah alur dari suatu program, dan dapat membantu mengorganisasikan seluruh elemen pembuatan program aplikasi. Struktur navigasi yang digunakan adalah struktur navigasi hierarki. Berikut ini merupakan rancangan struktur navigasi untuk implementasi aplikasi pengenalan hewan bermetamorfosis dengan menggunakan augmented reality berbasis android.

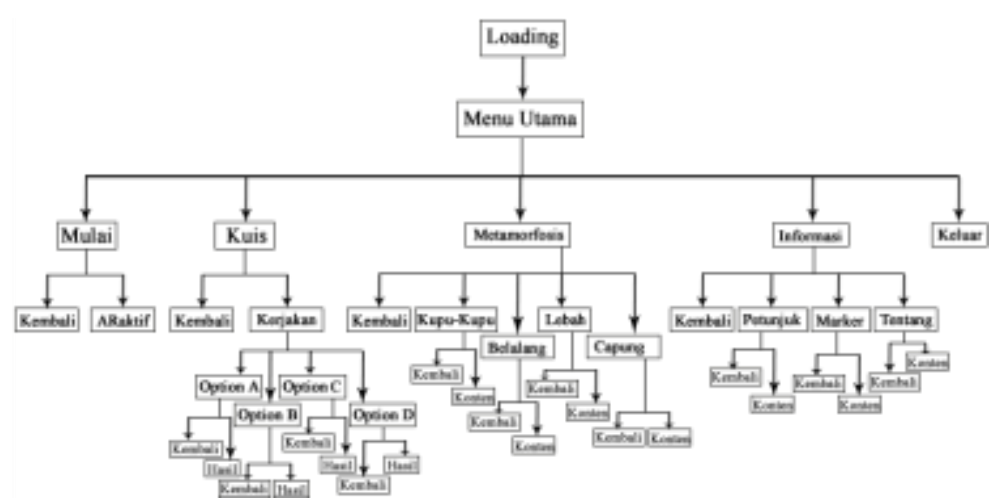

Gambar 3.1 Rancangan Struktur Navigasi

\subsubsection{Rancangan Tampilan}

Rancangan tampilan dalam proses pembuatan aplikasi sangat penting untuk dilakukan. Karena tampilan dalam sebuah aplikasi dapat menunjang ketertarikan user sebagai pengguna aplikasi. Tampilan aplikasi yang menarik dan mudah digunakan adalah suatu hal yang harus diperhatikan. Karakterisitik dalam tampilan aplikasi ini, sebagai berikut : 


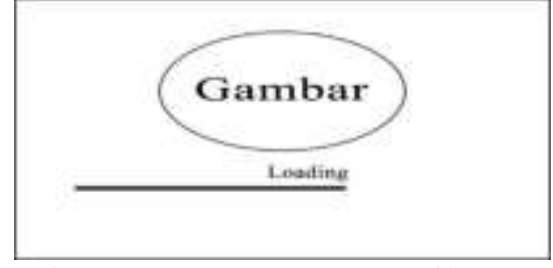

Gambar 3.2 Rancangan Tampilan Menu Loading

Keterangan :

Tampilan awal hanya terdapat sebuah gambar dan loading, menu ini sendiri akan berfungsi sebagai memuat data aplikasi.

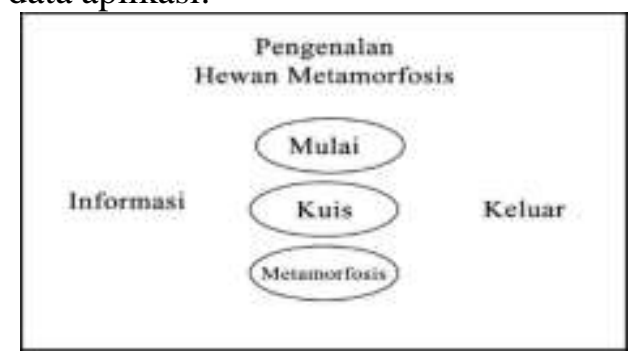

Gambar 3.3 Rancangan Tampilan Menu Utama

Keterangan :

Pertama kali pengguna membuka aplikasi pengenalan hewan bermetamorfosis akan melihat tampilan layar halaman menu utama seperti pada gambar 3.4. Tampilan Menu utama adalah halaman inti dari aplikasi ini, didalam halaman ini terdapat tulisan Pengenalan hewan Metamorfosis, dan terdapat 5 tombol pilihan yang akan digunakan user, masing-masing terdapat tombol pilihan yang akan berfungsi untuk memilih menu yang akan digunakan.

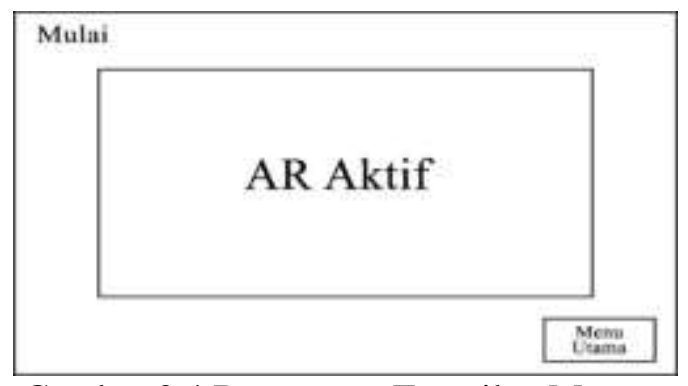

Gambar 3.4 Rancangan Tampilan Menu Mulai

Keterangan :

Pada saat pengguna menekan tombol mulai akan menampilkan sebuah kamera yang bertujuan untuk menampilkan objek 3D dari Marker Augmented Reality yang telah dibuat. 3D objek yang dibuat ada 4 hewan yaitu, kupu-kupu, belalang, lebah dan capung. Ada berbagai objek 3D dari proses metamorfosis mulai dari telur, ulat/larva, kepompong/pupa dan hewan dewasa yang diperuntukan untuk hewan bermetamorfosis sempurna. Sedangkan untuk hewan yang bermetamorfosis tidak sempurna mulai dari telur, nimfa dan imago/hewan dewasa.

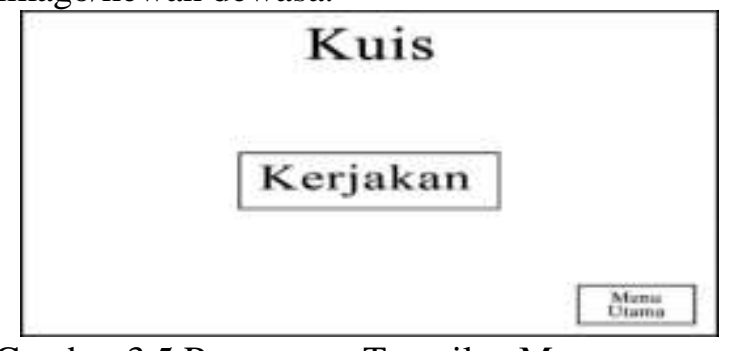

Gambar 3.5 Rancangan Tampilan Menu Kuis

Keterangan :

Pada saat pengguna mengklik tombol kuis akan menampilkan tampilan gambar dan terdapat tombol kerjakan yang berfungsi untuk menampilkan soal-soal pertanyaan yang bisa dijawab.
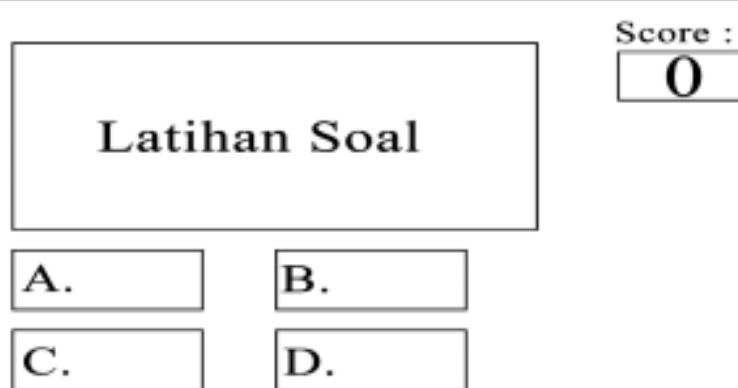

Gambar 3.6 Rancangan Tampilan sub-
menu kuis

Keterangan :

Pada saat pengguna mengklik tombol kerjakan maka akan muncul sub-menu pertama dari menu kuis. Yang berisikan pertanyaan-pertanyaan soal tentang objek yang ada di aplikasi ini. Apabila jawabannya benar maka diberi nilai 20 dan apabila jawabannya salah maka tidak mendapatkan nilai atau mendapatkan nilai 0 . Begitu juga sampai akhir pertanyaan.

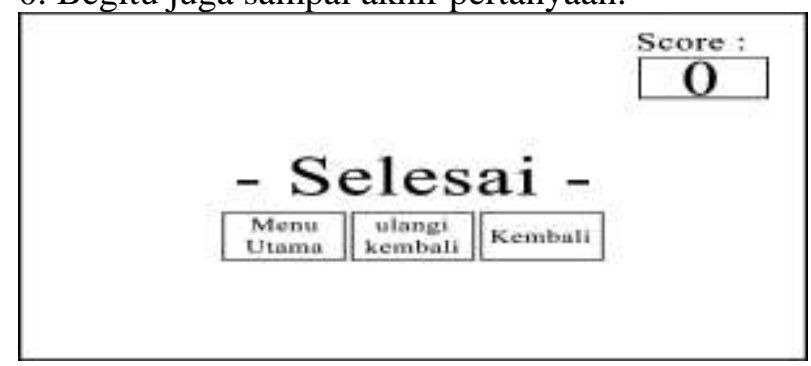


Gambar 3.7 Tampilan sub-menu kedua dari menu kuis

Keterangan :

Pada saat pengguna menyelesaikan soal-soal yang telah diberikan. Maka selanjutnya akan menampilkan tampilan score/nilai dari hasil menjawab soal-soal di halaman sub-menu sebelumnya. Hasil yang ditampilkan berupa angka mulai dari 20, 40,60 dan 100. Setelah itu tekan tombol kembali untuk kembali kemenu halaman sebelumnya. ulangi kembali yaitu ke menu halaman kuis untuk mengerjakan soal-soal kembali atau tekan kembali untuk kembali ke menu utama.

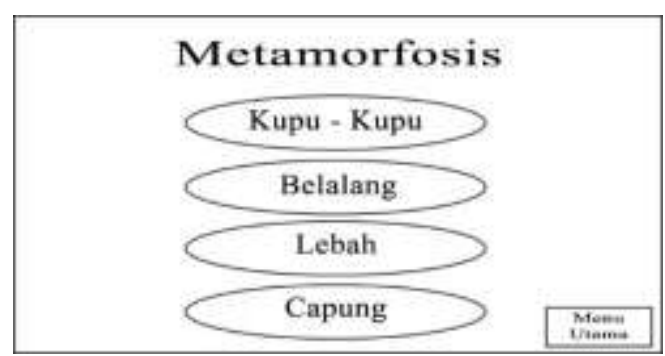

Gambar 3.8 Rancangan Tampilan Menu Metamorfosis

Keterangan :

Pada saat pengguna mengklik tombol metamorfosis maka akan menampilkan tampilan menu yang berisikan dengan 4 tombol yang bertuliskan daftar hewan.

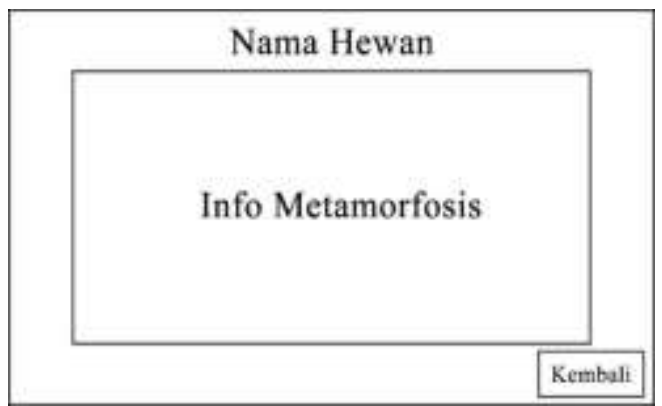

Gambar 3.9 Tampilan Sub-Menu metamorfosis

Keterangan :

Pada saat pengguna mengklik tombol salah satu nama hewan tersebut. Lalu, akam menampilkan tampilan yang berisikan penjelasan dan informasi-informasi umum tentang hewan tersebut yang ada di aplikasi ini.

\section{Informasi}

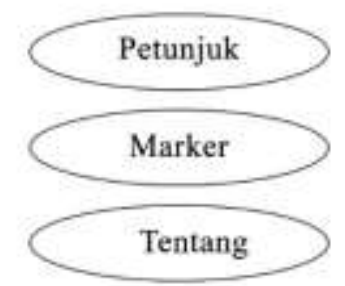

Gambar 3.10 Tampilan Menu Informasi Keterangan :

Pada saat pengguna mengklik tombol Informasi. Maka akan menampilkan tampilan yang berisikan tiga tombol yaitu, petunjuk, marker dan tentang. Pada tombol petunjuk berfungsi untuk menjelaskan penggunaan aplikasi yang diperuntukan untuk pengguna. Lalu tombol marker untuk menampilkan marker yang akan digunakan. Dan terakhir tombol Tentang berfungsi untuk menampilkan informasi data pribadi dari pembuat aplikasi tersebut.

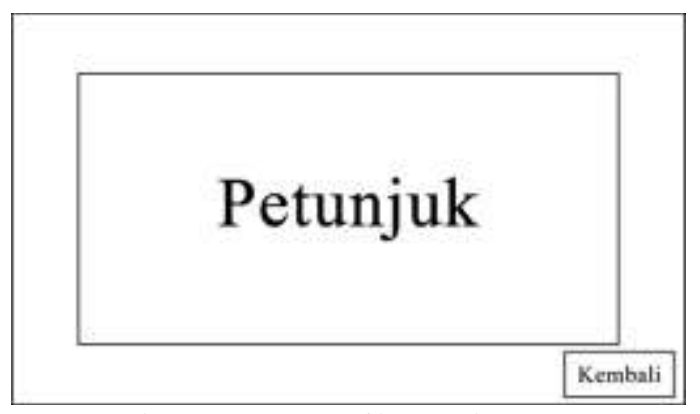

Gambar 3.11 Tampilan Sub-Menu Informasi dari Petunjuk

Keterangan :

Pada saat pengguna mengklik tombol pada menu Informasi tersebut. Maka akan menampilkan tampilan yang berisikan penjelasan dan informasiinformasi tentang penggunaan aplikasi yang diperuntukkan untuk pengguna.

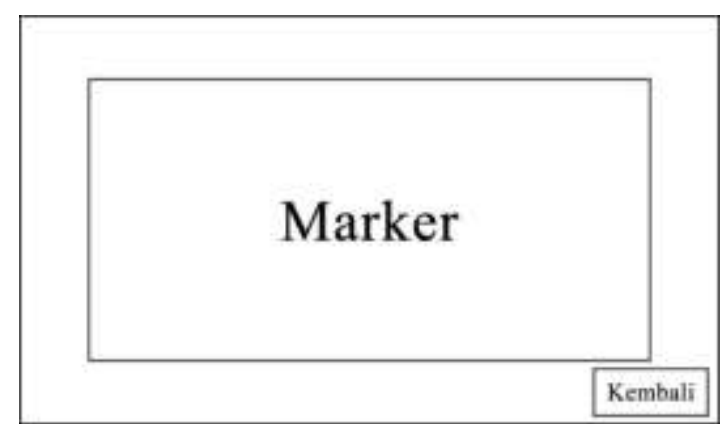


Gambar 3.12 Tampilan Sub-Menu Informasi dari Marker

Keterangan :

Pada saat pengguna mengklik tombol pada menu Informasi tersebut. Maka akan menampilkan tampilan yang berisikan penjelasan tentang marker yang akan digunakan untuk penggunaan aplikasi yang diperuntukkan untuk pengguna.

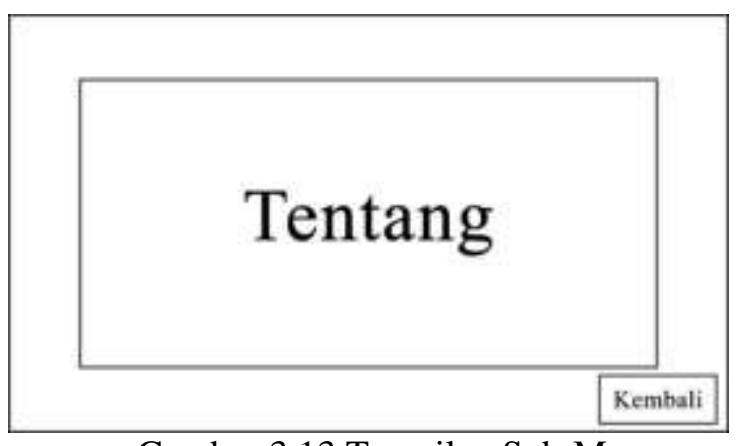

Gambar 3.13 Tampilan Sub-Menu Informasi dari Tentang

Keterangan :

Pada saat pengguna mengklik tombol pada menu Informasi tersebut. Maka akan menampilkan tampilan yang berisikan penjelasan dan informasi-informasi tentang data pribadi dari pembuat aplikasi tersebut. Berikut button keterangan yang digunakan pada aplikasi ini adalah sebagai berikut :

\subsection{Pengumpulan Bahan (Material Collecting)}

Sesuai dengan desain yang telah dibuat, maka dapat di temukan beberapa konten multimedia yang di butuhkan dalam pembuatannya aplikasi ini, dan berikut adalah komponen yang telah didapat.

\subsubsection{Analisa Kebutuhan Perangkat Keras (Hardware)}

Tabel 3.2 Harga Perangkat Laptop dan

\begin{tabular}{|r|c|c|}
\multicolumn{3}{c}{ Mobile } \\
\hline $\mathrm{N}$ & Nama & Tipe \\
$\mathrm{o}$ & & A455L Core \\
\hline 1 & Laptop & i5 \\
& ASUS & \\
\hline & A455L & Redmi 4A \\
\hline 2 & Xiaomi Redmi & \\
\hline \multicolumn{3}{|c|}{ Total } \\
\hline
\end{tabular}

\subsubsection{Analisa Kebutuhan Perangkat Lunak (Software)}

Tabel 3.3 Nama Status Perangkat Software

\begin{tabular}{|c|l|c|}
\hline No & \multicolumn{1}{|c|}{ Nama } & Status \\
\hline 1. & $\begin{array}{l}\text { Microsoft Windows } \\
10 \text { 64-bit }\end{array}$ & Based \\
\hline 2. & Unity 3D & Freeware \\
\hline 3. & Android Vuforia SDK & Freeware \\
\hline 4. & Blender & Freeware \\
\hline 5. & CorelDraw X7 & Trial \\
\hline 6. & $\begin{array}{l}\text { Java Development Kit } \\
\text { (JDK) }\end{array}$ & Freeware \\
\hline 7. & $\begin{array}{l}\text { Android Studio } \\
\text { Software } \\
\text { Development Kit } \\
\text { (SDK) }\end{array}$ & Freeware \\
\hline
\end{tabular}

\subsubsection{Analisa Kebutuhan Teks}

Pembuatan media pembelajaran pengenalan hewan bermetamorfosis dengan menggunakan Augmented Reality ini dibutuhkan teks untuk tampilan dalam aplikasi ini. berikut adalah kebutuhan teks yang digunakan di dalam aplikasi ini, adalah sebagai berikut :

Gambar 3.4 Analisa Kebutuhan Teks

\begin{tabular}{|r|c|c|c|}
\hline No. & Teks & Type & Size \\
\hline 1 & Times New & Serif & 982 \\
& Roman & Typeface & $\mathrm{Kb}$ \\
\hline 2 & Adobe Caslon Pro & Serif & 163 \\
& & Typefaces & $\mathrm{Kb}$ \\
\hline 3 & Prestige Elite Std & Monospaced & 36 \\
& Bold & Typeface & $\mathrm{Kb}$ \\
\hline 4 & Comic Sans Ms & San-Serif & 234 \\
& & Typeface & $\mathrm{Kb}$ \\
\hline 5 & Bakery Regular & Stereo & 101 \\
& & TypeFaces & $\mathrm{Kb}$ \\
\hline
\end{tabular}

\subsubsection{Analisa Kebutuhan Gambar}

Harga Pembuatan media pembelajaran pengenalan hewan

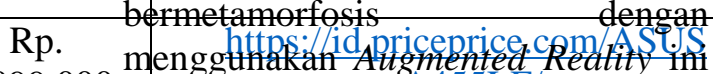
7.099.000 mibutuhkan gamb $4551 \mathrm{H}$. W tampilan dalam apliekasa, $20.08-19$ - $11: 58$ alah

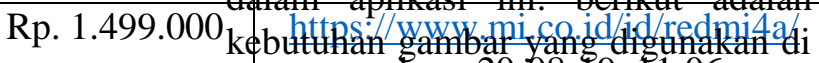

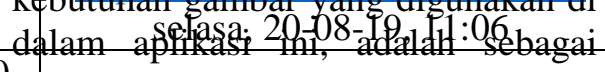

Tabel 3.5 Analisa 
Kebutuhan Gambar

\begin{tabular}{|c|c|c|c|}
\hline No & Gambar & Fungsi & Format \\
\hline 1. & 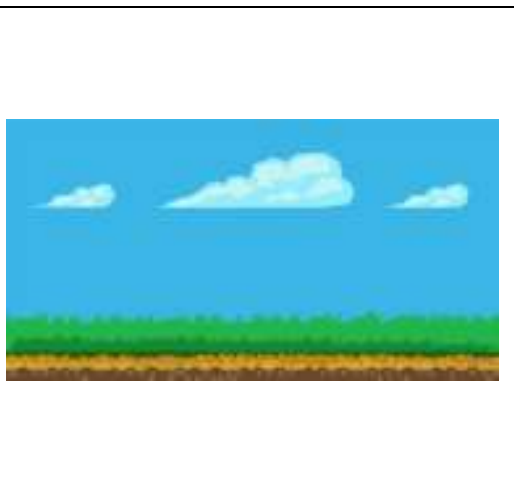 & $\begin{array}{l}\text { Gambar: latar background } \\
\text { Warna : } \\
\text { \#3CB5E6 } \\
\text { \#96ECF7 } \\
\text { \#C8F4F7 } \\
\text { \#6A482B } \\
\text { \#906D4E } \\
\text { \#D8A736 } \\
\text { \#B88717 } \\
\text { \#265A15 } \\
\text { \#23B44C }\end{array}$ & .jpeg \\
\hline 2. & 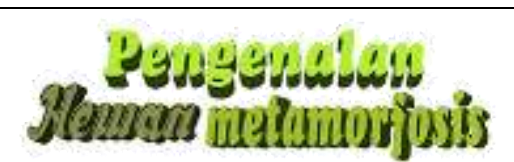 & $\begin{array}{l}\text { Gambar : Judul Aplikasi } \\
\text { Warna : \#B2EB34 \#8F9A51 \#9DBD2D } \\
\text { \#4D4D4D }\end{array}$ & .jpeg \\
\hline 3. & & $\begin{array}{l}\text { Gambar: Judul menu metamorfosis } \\
\text { Warna : \#26A78D \#FFFFFF }\end{array}$ & .jpeg \\
\hline 4. & & $\begin{array}{lllr}\text { Gambar: Pohon1 } & & \\
\text { Warna }: & \# 785 C 35 & \# 846433 & \text { \#3B280A } \\
\text { \#492903 } & \# 08501 \mathrm{E} & \# 031 \mathrm{BC5} & \text { \#0E3613 } \\
\text { \#247624 } & \# 389137 & \text { \#745655 } & \text { \#6DC32E } \\
\text { \#49954B } & \# 186924 & \text { \#ACE137 } & \text { \#003B19 } \\
\text { \#66A346 } & \text { \#83C257 } & & \end{array}$ & png \\
\hline 5. & & $\begin{array}{l}\text { Gambar: Pohon1 } \\
\text { Warna : \#653713 \#7A5132 \#8D5F3D } \\
\text { \#126628 \#031C06 \#DB3311 \#D53F0F } \\
\text { \#002D06 \#47A22D \#48954D \#4EA352 } \\
\text { \#ACCE46 \#2D8813 \#B9D6C \#AFDD71 } \\
\text { \#96C960 \#86AF4F \#005F2F }\end{array}$ & png \\
\hline 6. & & $\begin{array}{l}\text { Gambar: Tombol Mulai } \\
\text { Warna : \#300914 \#61343F \#936572 } \\
\text { \#EDBAC6 \#5F2E3D \#333347 }\end{array}$ & png \\
\hline 7. & Met & $\begin{array}{l}\text { Gambar: Tombol Kuis dan Metamorfosis } \\
\text { Warna : \#383854 \#CED806 \#C2CA28 } \\
\text { \#518A0B \#ABD514 \#FFFFFF \#999999 } \\
\text { \#000000 }\end{array}$ & png \\
\hline 8. & & $\begin{array}{l}\text { Gambar : Tombol Option A dan B } \\
\text { Warna : \#4973A0 \#B0C0D5 \#112E6C } \\
\text { \#F6AA00 \#DB9302 \#FFCB55 \#FFFFFF } \\
\text { \#FEE4A7 \#F6B736 \#000000 }\end{array}$ & png \\
\hline 9. & Lebah & $\begin{array}{l}\text { Gambar : Tombol Kupu-Kupu, Lebah, } \\
\text { Petunjuk, dan Tentang } \\
\text { Warna : \#F58F40 \#FBC46C \#999999 } \\
\text { \#A4D8E6 \#4BBFD7 \#3288A1 \#FFFFFF } \\
\text { \#43BFD3 \#000000 }\end{array}$ & .png \\
\hline
\end{tabular}




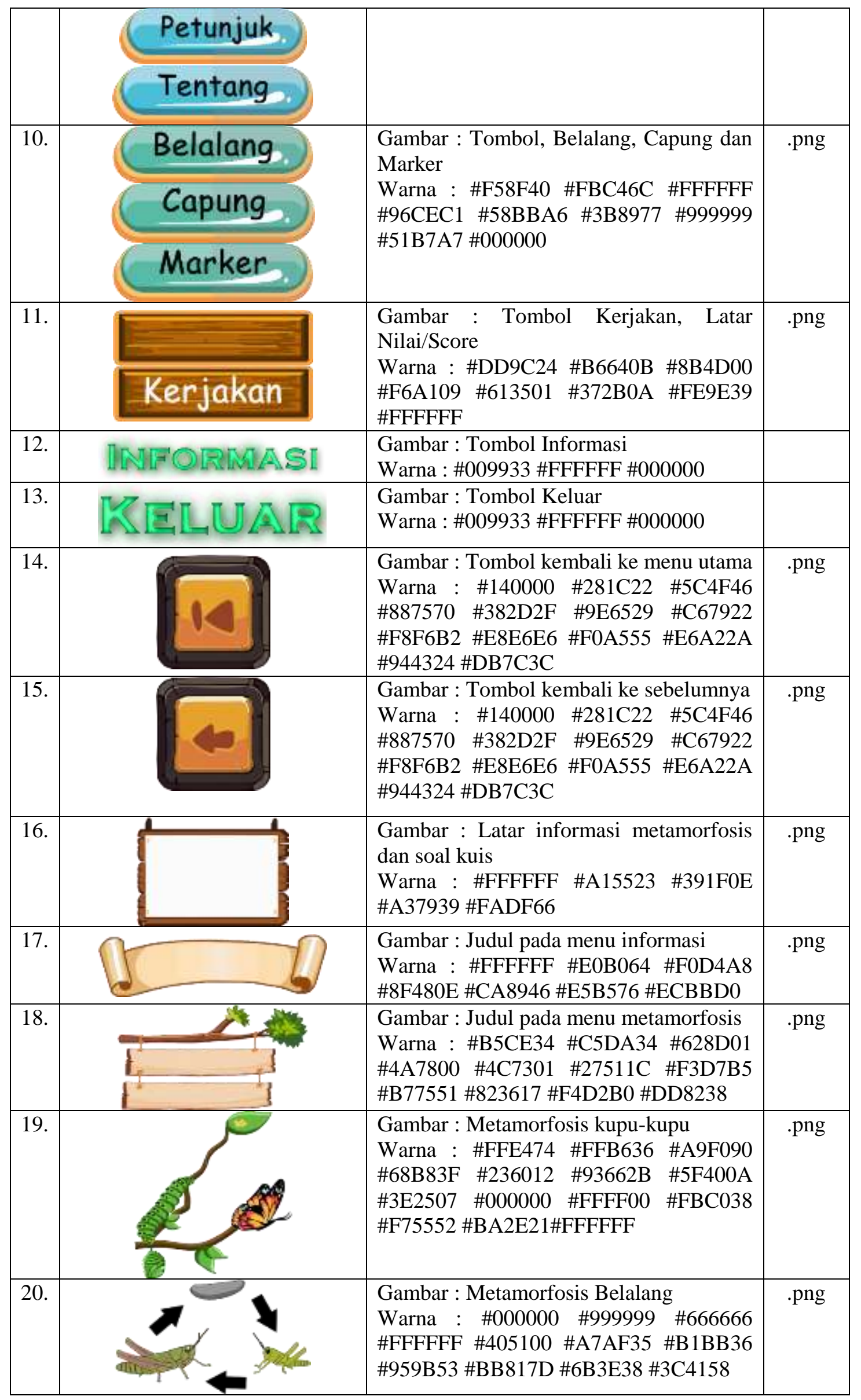




\begin{tabular}{|l|l|l|l|}
\hline 21. & $\begin{array}{l}\text { Gambar : Metamorfosis Lebah Warna : } \\
\text { \#FFF754 \#CD6A15 \#F9A61A \#FDB813 } \\
\text { \#FBCE01 \#D29930 \#F4F4F4 \#ADA2A6 } \\
\text { \#9A8572 \#663300 \#FFFF99 \#CC9933 } \\
\text { \#FFFFCC \#FFCC99 }\end{array}$ & \\
\hline
\end{tabular}

\subsubsection{Analisa Kebutuhan Audio}

Pembuatan media pembelajaran pengenalan hewan bermetamorfosis dengan menggunakan Augmented Reality ini dibutuhkan Audio untuk tampilan dalam aplikasi ini. berikut adalah kebutuhan Audio yang digunakan di dalam aplikasi ini, adalah sebagai berikut :

Tabel 3.6 Kebutuhan Audio

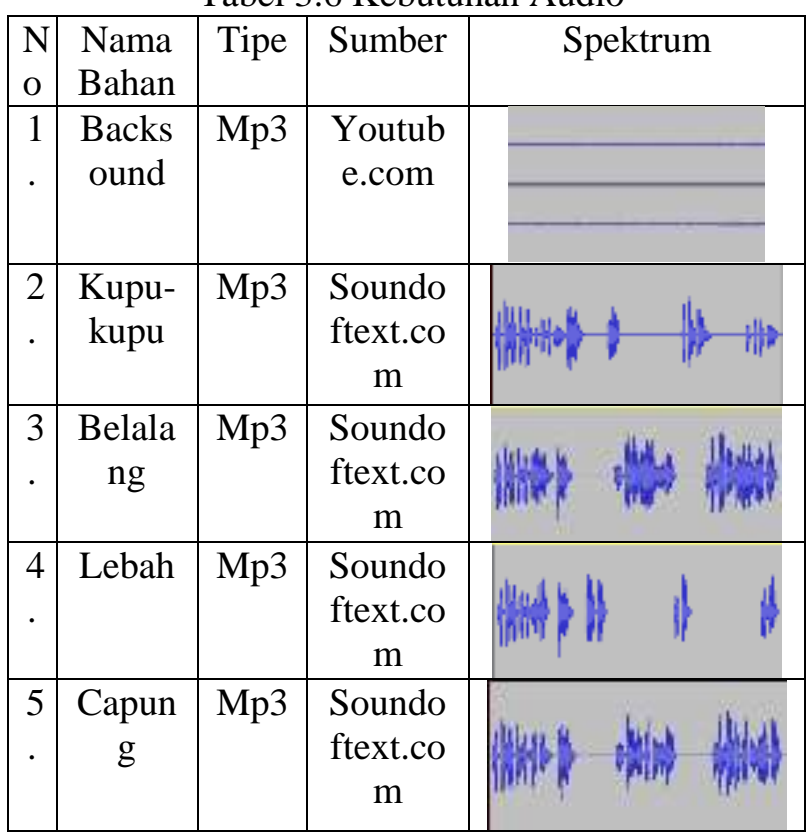

\section{HASIL DAN PEMBAHASAN}

Hasil aplikasi media pembelajaran hewan bermetamorfosis dengan menggunakan Augmented Reality berbasis Android. Yang telah dibuat dengan unity dan vuforia ini akan dijelaskan sebagai berikut :

\section{a. Tampilan Menu Loading}

Tampilan menu Loading merupakan halaman untuk memuat data. Pada halaman ini terdiri logo unsera, logo aplikasi dan tampilan proses memuat data.

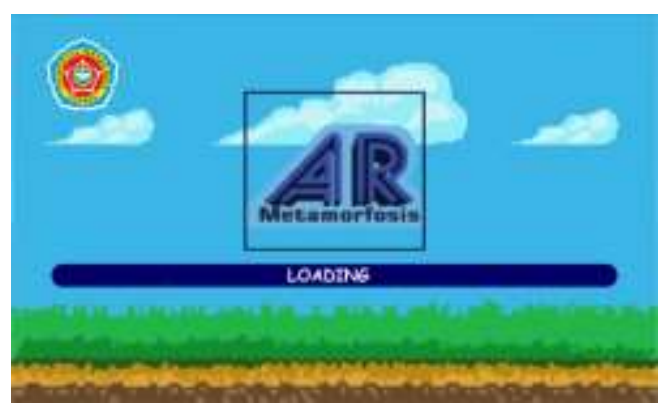

Gambar 4.1 Tampilan Menu Loading

b. Tampilan Menu Utama

Tampilan menu utama merupakan halaman utama pada aplikasi ini, yang dimana menu ini akan menampilkan beberapa pilihan yang akan dipilih ole pengguna. Pada halaman ini terdapat 5 buah tombol yang akan menampilkan menu yang berbeda.

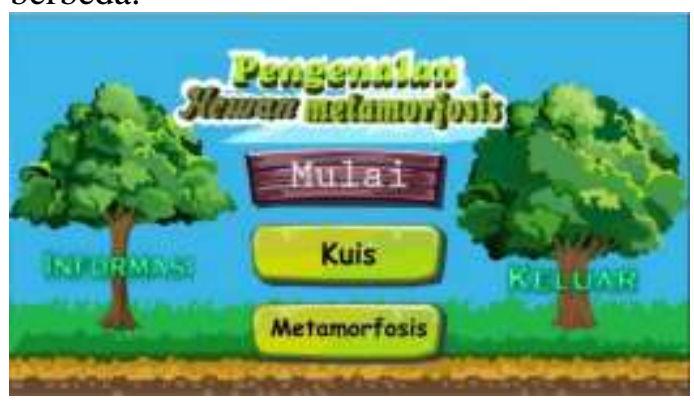

Gambar 4.2 Tampilan Menu Utama

c. Tampilan Menu Mulai

Tampilan menu mulai merupakan tampilan yang menampilkan objek 3D dari Marker Augmented Reality yang telah dibuat. Ada berbagai objek 3D dari proses metamorfosis mulai dari telur, ulat/larva, kepompong/pupa dan hewan dewasa yang diperuntukan untuk hewan bermetamorfosis sempurna. Sedangkan untuk hewan yang bermetamorfosis tidak sempurna mulai dari telur, nimfa dan imago/hewan dewasa. 


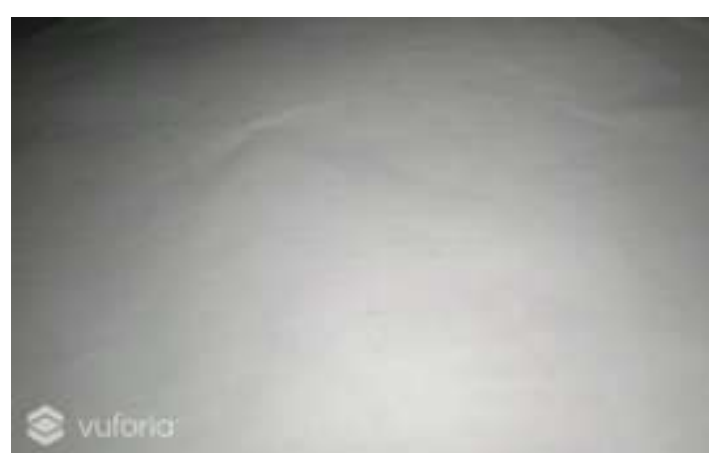

Gambar 4.3 Tampilan Menu Mulai

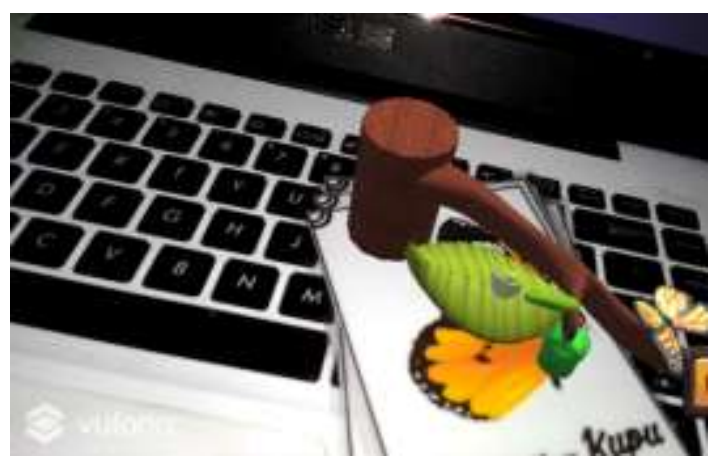

Gambar 4.4 Tampilan Metamorfosis kupu-kupu

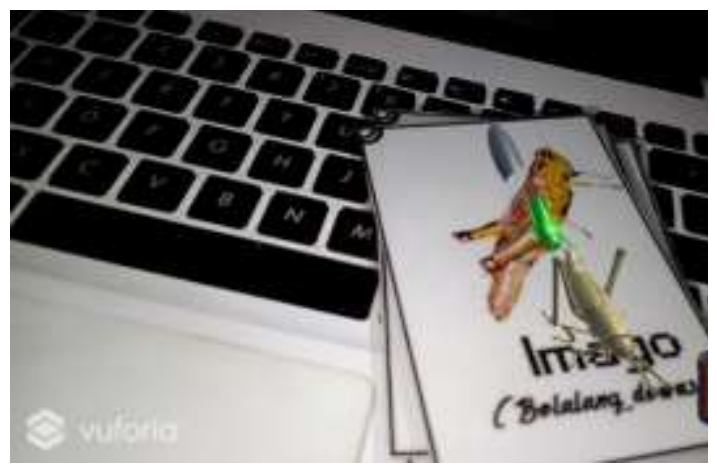

Gambar 4.5 Tampilan Metamorfosis belalang

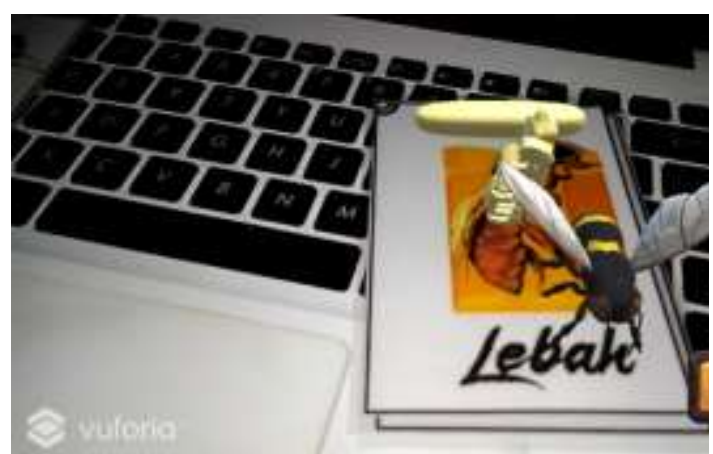

Gambar 4.6 Tampilan metamorfosis lebah

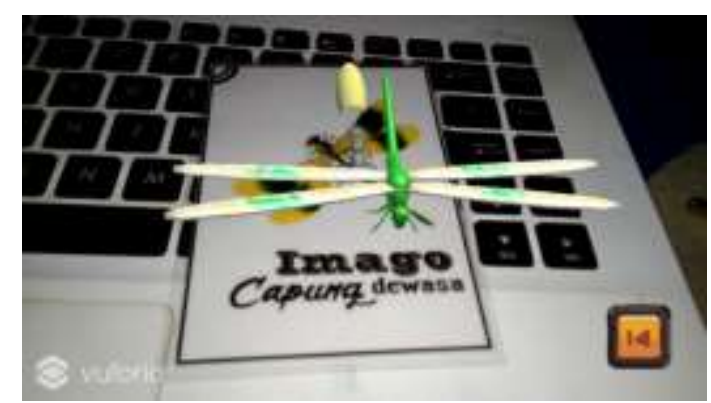

Gambar 4.7 Tampilan Metamorfosis capung

d. Tampilan Menu Kuis

Tampilan menu kuis menampilkan pertanyaan-pertanyaan yang berhubungan dengan aplikasi ini. setiap pertanyaan bernilai 20 poin. Ketika berhasil menjawab semua mendapatkan nilai 100 poin.

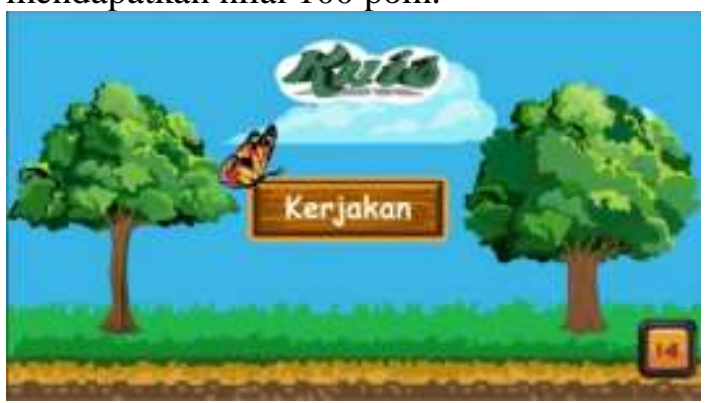

Gambar 4.8 Tampilan Menu Kuis

Tampilan pertanyaanpertanyaan yang akan di jawab oleh pengguna yaitu sebagai berikut :

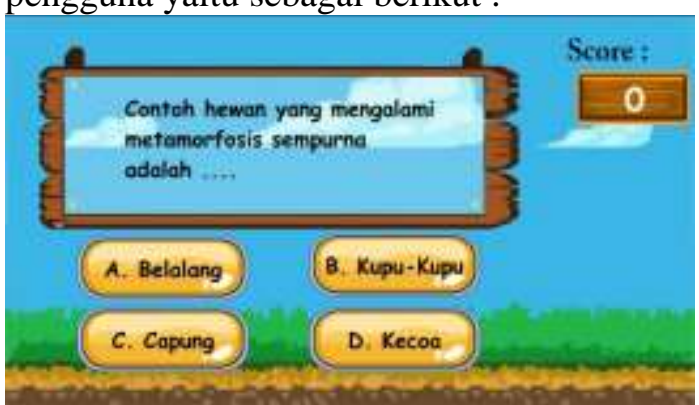

Gambar 4.9 Tampilan Pertanyaan 1. 


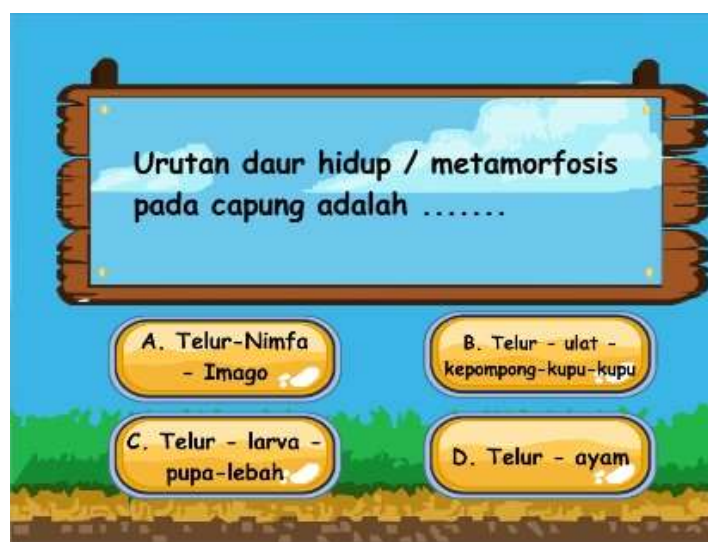

Gambar 4.10 Tampilan Pertanyaan 2.

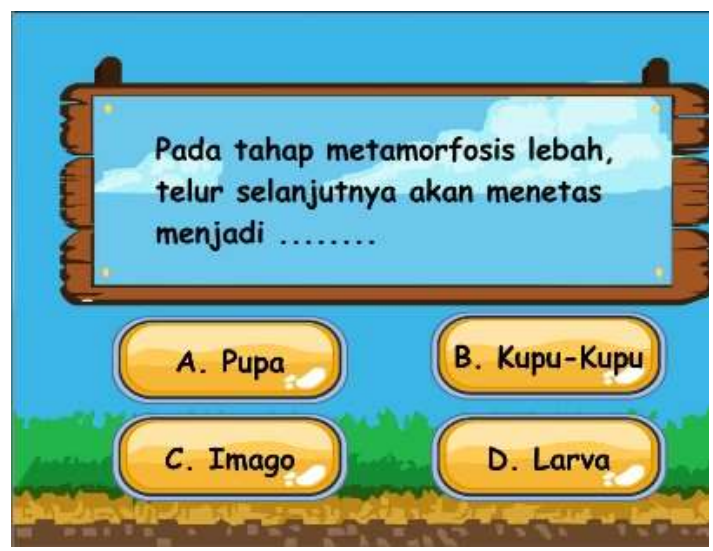

Gambar 4.11 Tampilan Pertanyaan 3.



Gambar 4.12 Tampilan Pertanyaan 4.

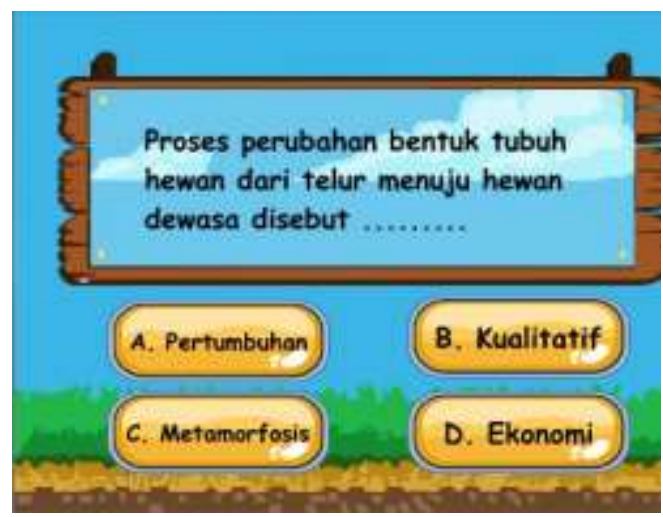

Gambar 4.13 Tampilan Pertanyaan 5.

Tampilan Score dan Selesai yang telah menjawab soal oleh pengguna dan tulisan selesai yaitu sebagai berikut :

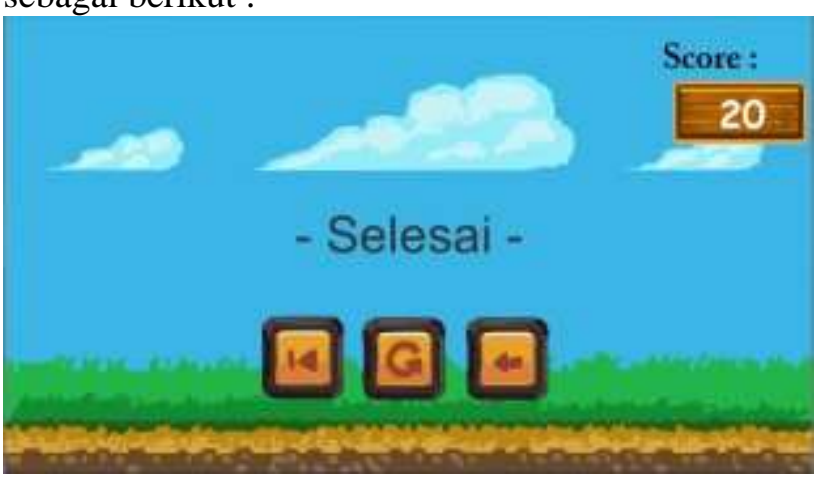

Gambar 4.14 Tampilan Score dan Selesai

e. Tampilan Menu Metamorfosis

Tampilan menu metamorfosis merupakan menu untuk menjelaskan tentang masing-masing hewan yang berada di aplikasi ini adalah sebagai berikut :

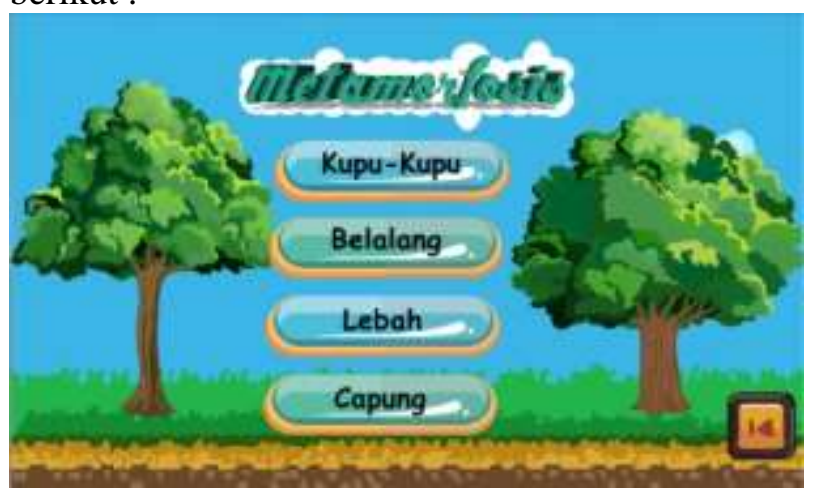

Gambar 4.15 Tampilan menu metamorfosis

Tampilan Menu metamorfosis salah satunya adalah metamorfosis kupukupu yang menjelaskan tentang informasi kupu-kupu yaitu sebagai berikut : 


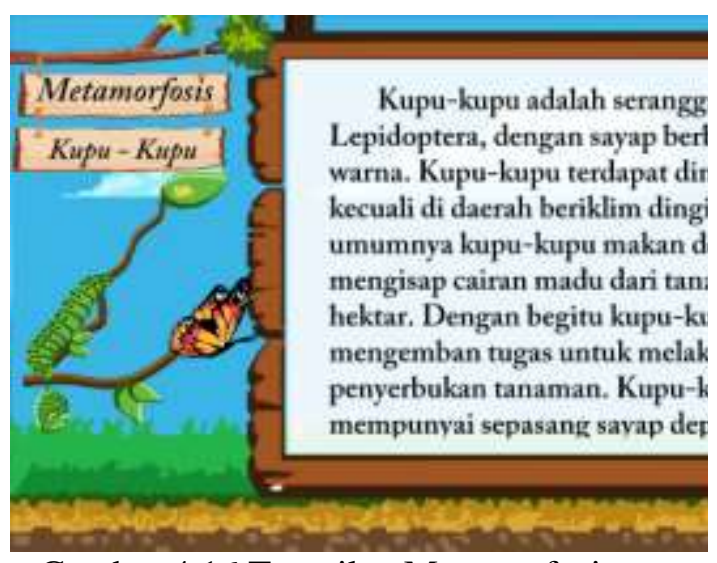

Gambar 4.16 Tampilan Metamorfosis

Kupu-Kupu

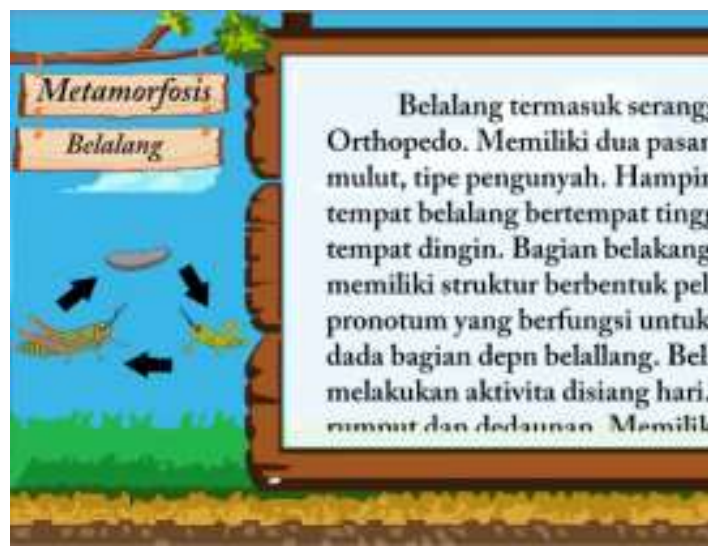

Gambar 4.17 Tampilan Metamorfosis Belalang

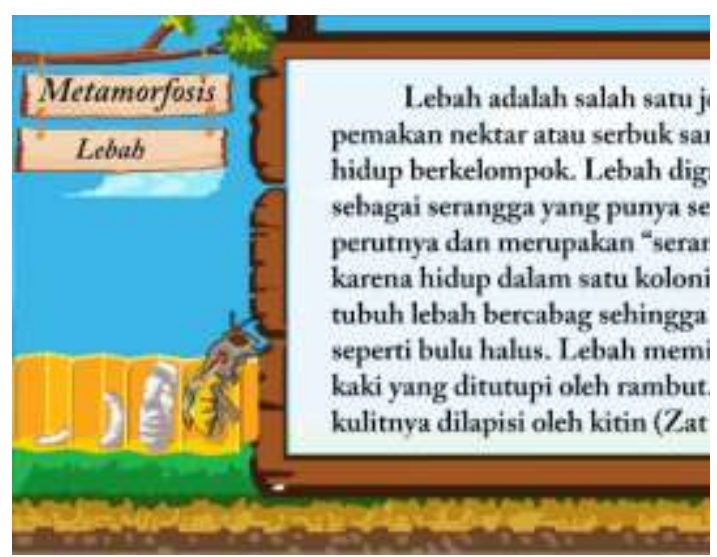

Gambar 4.18 Tampilan Metamorfosis Lebah

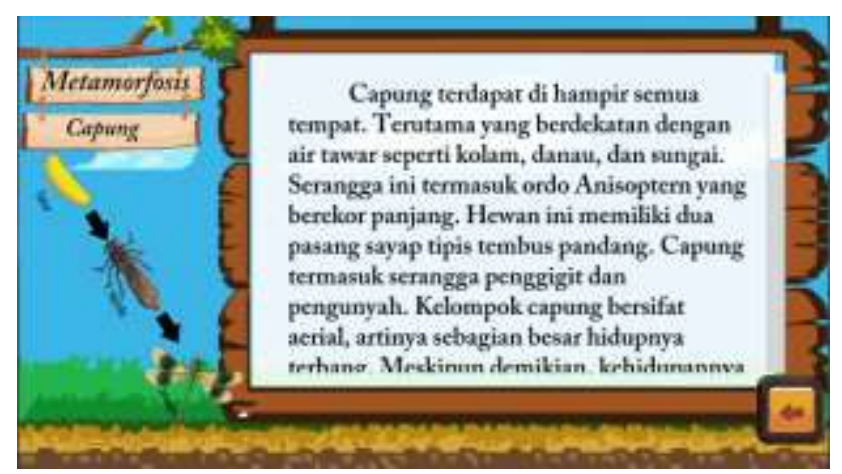

Gambar 4.19 Tampilan Metamorfosis Capung

f. Tampilan Menu Informasi

Tampilan Menu Informasi berisikan tombol petunjuk, marker dan tentang. Tampilan menu informasi adalah sebagai berikut :

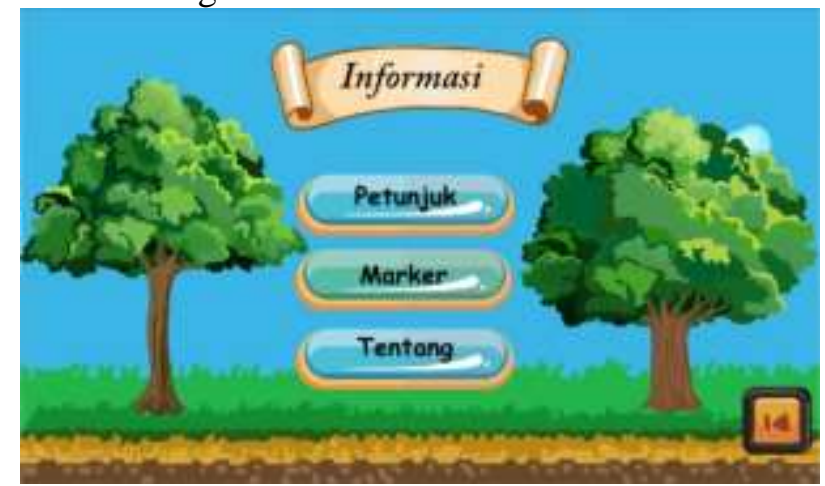

Gambar 4.20 Tampilan Menu Informasi

Tampilan menu informasi submenunya adalah petunjuk. Petunjuk menjelaskan tentang petunjuk untuk menjalankan aplikasi untuk penguna. Tampilan menu petunjuk yaitu sebagai berikut :

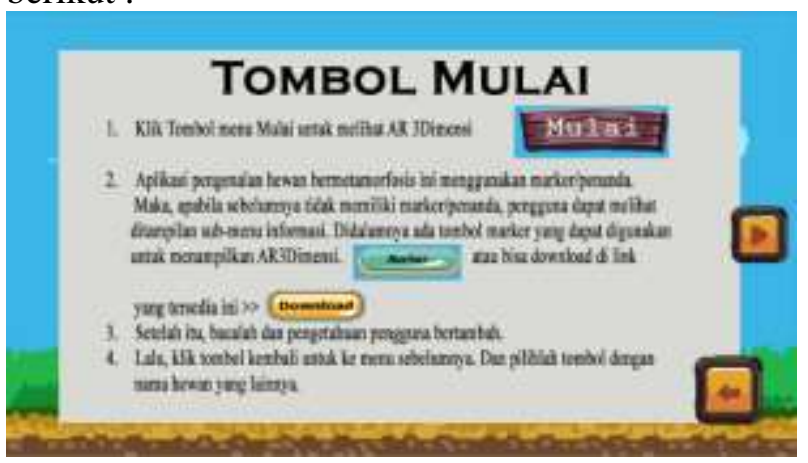

Gambar 4.21 Tampilan Menu Petunjuk

Tampilan sub-menu dari informasi yaitu menu marker. Menu marker 
berisikan tentang marker yang akan digunakan. Tampilan menu marker adalah sebagai berikut :

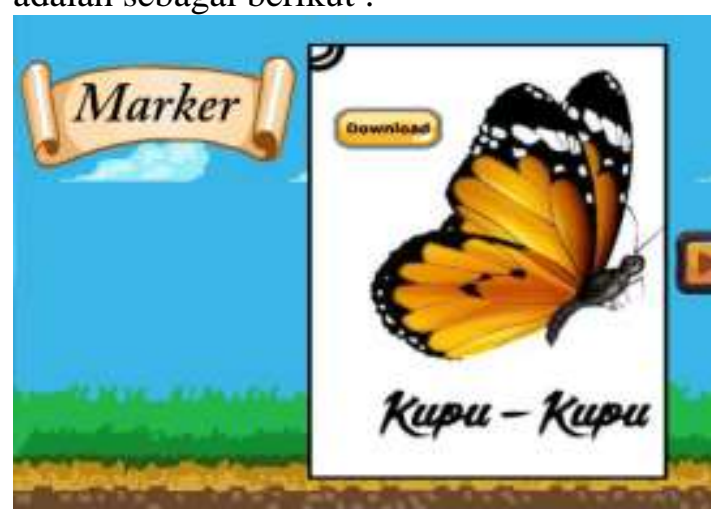

Gambar 4.22 Tampilan Menu Marker

Tampilan sub-menu dari informasi yaitu menu tentang. Menu tentang merupakan penjelasan tentang aplikasi dan data pribadi dari pembuatan aplikasi ini. tapilan menu tentang adalah sebagai berikut :

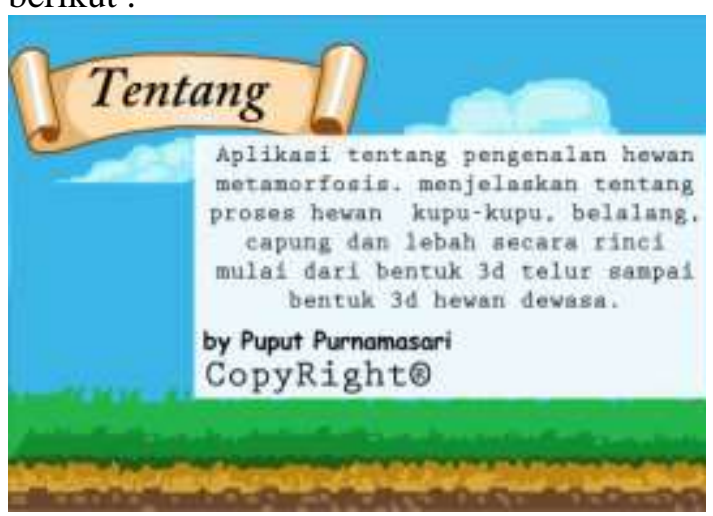

Gambar 4.23 Tampilan Menu

Tentang

\section{KESIMPULAN}

Dari hasil penelitian, perancangan dan pembahasan pada Aplikasi Pengenalan Hewan Bermetamorfosis Dengan Menggunakan Augmented Reality Berbasis Android ini dapat disimpulkan yaitu :

1. Media pembelajaran pengenalan hewan metamorfosis dibuat dengan menggunakan software unity. Dengan memanfaatkan teknologi augmented reality pada aplikasi hewan metamorfosis yang didalam aplikasi terdapat tampilan hewan metamorfosis dalam bentuk gambar 3D. Hal tersebut dapat membuat siswa mudah untuk memahami dalam mengenali hewan metamorfosis.

2. Media pembelajaran ini di implementasikan untuk SD Negeri Talaga Mancak Serang yang dikemas kedalam bentuk media pembelajaran yang diperuntukan untuk pengguna smarthphone berbasis android. hal tersebut dapat membuat siswa jadi lebih mudah untuk mempelajari pengenalan tentang hewan metamorfosis di sekitar lingkungannya. 


\section{REFERENSI}

Adriyadi, Anggi. (2011). Augmented Reality with ARToolkit, Reality Leaves a lot to Imagine. Lampung: Augmented Reality Team.

Ambariani, Ni Luh Putu Novi; Purnawan, I Ketut Adi; dan Wibawa, Kadek Suar. (2017). Aplikasi Pengenalan Jenis Kupu-Kupu Langka Berbasi Augmented Reality. 207-218.

Binanto, Iwan. (2010). Multimedia Digital Dasar Teori dan Pengembangannya. Yogyakarta: ANDI.

Dhiyatmika, I Dewa Gede Wahya; Putra, I Ketut Gede Darma; dan Mandenni, Ni Made Ika Marini. (2015). Aplikasi Augmented Reality Magic Book Pengenalan Binatang Untuk Siswa TK. 120127.

Hanif, Ibrahim. (2014). Jago CorelDraw. Jakarta Timr: Dunia Komputer.

Haryanto. (2013). Sains jilid 4 Untuk SD/MI Kelas IV. Erlangga.

Hendratman, Hendi. (2015). The Magic Of Blender 3d Modelling. Bandung: Informatika.

Hidayat, Toni; dan Setiyadi, Didik. (2017). Animasi Pop UP Pengenalan Hewan Beserta Klasifikasinya Kepada Anak Sekolah Dasar Menggunakan Teknologi Augmented Reality. 65-74.

Kadir, Abdul. (2013). From Zero To A Pro-Pemrograman Aplikasi Android. Yogyakarta: ANDI.

Karundeng, Christian O; Mamahit, Dringhuzen J; dan Sugiarso, Brave A. (2018). Rancang Bangun Aplikasi Pengenalan Satwa Langka di Indonesia Menggunakan Augmented Reality. 107-118.

Meilani, Gina Rahayu. (2018). Membangun Aplikasi Augmented Reality Dengan Unity. Surabaya: Sinar Mas.

Munir. (2013). Multimedia Konsep dan Aplikasi dalam Pendidikan. Bandung: Alfabeta.

Nofiandi, Selamet; Listyorini, Tri; dan Susanto, Arief. (2017). Animasi
Metamorfosis Kupu-Kupu. 299308.

Nurmutiah, Tamara. (2009). Ensiklopedia. Yogyakarta: ANDI.

Pamoedji, Andre Kurniawan; Maryuni; dan Sanjaya, Ridwan. (2017). Mudah Membuat Game Augmented Reality (AR) dan Virtual Reality (VR) dengan Unity 3D. Jakarta: Elex Media Komputindo.

Seno dan Bowo. (2013). Kupas Tuntang Aplikasi Android Bagi Penggila Traveling. Yogyakarta: ANDI.

Sergey, Smirnov. (2002). Software Testing: Black-Box Techniques. 1-4

Sutanto, Purwo; Handayani; dan Sarjan. (2004). Sains 4. Klaten: Sahabat.

Wahyudi, Andria Kusuma; Mewo, Freandy Fernando; dan Ganda, Sabatino. (2018). Perangkat Visualisasi Metamorfosis KupuKupu Menggunakan Animated Augmented Reality. 69-80.

William, Laurie. (2006). Testing Overview dan Black-Box Testing Techniques.35-39

Yulianty, Rani. (2013). Ensiklopedia Dunia Serangga. Yogyakarta: ANDI. 